Journal of Advanced Research in Fluid Mechanics and Thermal Sciences

\title{
A Numerical Approach to Study the Performance of Photovoltaic Panels by using Aluminium Heat Sink
}

\author{
Gabriel Setyohandoko ${ }^{1}$, Bayu Sutanto ${ }^{1}$, Rendy Adhi Rachmanto ${ }^{1}$, Dominicus Danardono Dwi Prija \\ Tjahjana ${ }^{1}$, Zainal Arifin ${ }^{1, *}$ \\ Sebelas Maret University, Surakarta, Central Java 57126 Indonesia
}

\section{ARTICLE INFO}

Article history:

Received 13 January 2020

Received in revised form 21 February 2020

Accepted 3 March 2020

Available online 26 April 2020

\section{Keywords:}

Photovoltaic panel; heat transfer; computational fluid dynamics; operating temperature; passive cooling; efficiency; heat sink

\section{ABSTRACT}

\begin{abstract}
The increase of operating temperature of photovoltaic (PV) panels due to excess heat from solar irradiance leads to a decrease in efficiency and the lifespan of PV panels. In this paper, a numerical model of temperature reduction of the photovol-taic panels by using air-cooled heat sink with $\mathrm{Re}=13100$ was studied. The heat sink was devised as an aluminum baseplate with perforated fins attached to its surface. The cooling efficiency was determined by comparing the simulation of the photovoltaic panel's performance with heat sink and without heat sink using ANSYS-Fluent software. The simulation results were presented by temperature distribution contour of the PV module and velocity profile of air moving through the heat sink. An average decrease of $13.1^{\circ} \mathrm{C}$ in temperature and increase of $0.8 \%$ in efficiency of the PV module was achieved on the model with heat sink, provid-ing a promising solution to overcome overheating PV panels.
\end{abstract}

Copyright @ 2020 PENERBIT AKADEMIA BARU - All rights reserved

\section{Introduction}

The ever-increasing global energy demand is amongst the biggest challenges for mankind in the $21^{\text {st }}$ century [1]. Renewable energy, especially solar energy, could be the solution for the growing demand of energy consumption. According to the 2000 World Energy Assessment by the United Nations Development Programme, the annual potential of solar energy was 1,575-49,837 exajoules (EJ) [2], several times larger than the annual global energy consumption, which was 567 EJ in 2013 [3].

Solar energy can be converted into electricity directly using devices based on semiconductor materials, such as photovoltaic (PV) panels. The working principle of PV panels is based on the photovoltaic effect, which is the generation of voltage and electric current in the semiconductor

\footnotetext{
* Corresponding author.

E-mail address: zainal_arifin@student.uns.ac.id (Zainal Arifin)
} 
material upon exposure to light [4]. This phenomenon happens when sunlight - which carries packets of energy called photon - hits the semiconductor material. Photons with certain level of energy, known as the "bandgap energy", excites the electrons within the material, so that the electrons freed from its covalent bond and produces electricity [5].

However, photons which have more energy than the bandgap energy exerted the extra amount of energy as heat when freeing electrons. Furthermore, ordinary PV panels could only convert 6 $20 \%$ of solar radiation into electricity, depending on the solar cell type and the climate conditions where the module is used [6]. The excess solar radiation becomes heat which could increase the temperature of the PV module and decrease the efficiency significantly.

The operating temperature of a PV panel has a crucial impact to the efficiency [7]. For every degree of temperature rise, crystalline silicon solar cells experienced a reduction in conversion efficiency of $\sim 0.4-0.5 \%$ [8]. The operating temperature of a PV module could reach up to $80^{\circ} \mathrm{C}$ in summer, causing a drastic reduction of efficiency [9]. Such extreme temperature increment caused by inefficient waste heat dissipation could even lead to irreversible damages to the solar cells such as delamination, micro-sized cracks, and deformation due to thermal stress [10].

There are two methods of PV module cooling, namely the active and the passive cooling method. Active cooling method utilizes mechanical and electrical devices, such as fans or pumps to drive the coolant, such as water or air that absorbs heat from PV module. There is additional power required to make the mechanical and electrical devices work in active cooling, which does not provide obvious benefit in the net gain of PV module efficiency [8].

On the other hand, passive cooling method does not require additional power since there are no mechanical and electrical devices involved. This method may uses additional parts which relies fully on the principles of convection heat transfer to direct the coolant flow to the PV module, such as thermosiphon or heat sink [11].

Passive cooling method developed by Ali et al., [12] to lower the operating temperature of PV module was based on the installation of aluminum heat sink to the PV module. The study was conducted by fabricating two heat sinks of different dimensions, a large one of $150 \mathrm{~mm} \times 100 \mathrm{~mm} \times$ $95 \mathrm{~mm}$ and a small one of $100 \mathrm{~mm} \times 100 \mathrm{~mm} \times 95 \mathrm{~mm}$. A temperature difference of $4.1^{\circ} \mathrm{C}$ and $2.73^{\circ} \mathrm{C}$ were noticed for the large and small heat sink, respectively.

Araki et al., [13] had designed a passive and simple heat sink consisted of a copper sheet on a heat-conductive epoxy-printed aluminum baseplate for cooling concentrated photovoltaic (CPV) modules. The experiment was conducted by mounting the solar cell on the heat sink and evaluating the cooling performance. Results of the experiment showed a difference of temperature between the ambient air and the solar cell of only $18^{\circ} \mathrm{C}$ for heat flux of $\sim 600 \mathrm{~W} / \mathrm{m}^{2}$.

Natarajan et al., [13] had numerically investigated the passive cooling performance of finattached aluminum heat sink for CPV modules. The module was modelled in 2D with the heat sink attached beneath the solar cells. The simulation resulted in a reduction of solar cell temperature of $14.8^{\circ} \mathrm{C}$ under heat flux of $1000 \mathrm{~W} / \mathrm{m}^{2}$.

An experiment of passive cooling on PV module conducted by Gotmare et al., [14] proposed an aluminum heat sink attached to the back side of a PV panel. The heat sink was consisted of fins with different sizes, number of perforations and perforation distance. The installation of fins resulted in a reduction of the panel temperature by $4.2 \%$. Moreover, an average power output increase of $5.5 \%$ was observed in the case of PV panel with fins.

Perforation influence on passive cooling for PV module has been studied by Abd-Elhady et al., [15] by drilling through holes on the free area of a PV panel and observing the performance through experimental and numerical methods. It had been found from the study that addition of holes assists in cooling the PV panel and decreased the overall surface temperature of the PV panel. An increase 
in the number of holes also decreases the PV panel temperature until a certain number of holes, where the average panel temperature decrease becomes marginal. Moreover, there is a critical diameter for the through holes, after which cooling of the panel decreases and the temperature increases.

Popovici et al., had numerically examined a passive cooling method with fin-attached copper heat sink for PV module [16]. In a 3D simulation model, the heat sink was attached beneath a layer with thermal characteristics of the PV cells. The study was conducted using ANSYS Fluent software, using variation of fin height, number of perforations, and fin inclination towards vertical axis. Results of simulations showed a temperature difference of $10^{\circ} \mathrm{C}$ and a $6.97-7.55 \%$ rise of maximum power produced by the PV panel, as compared to the base case.

The objective of this research is to solve the problem of overheating of PV panels by means of passive cooling using heat sink. A numerical model is developed to simulate the temperature distribution on the PV panel and velocity profile of the air passing through the heat sink. The model is realized by using ANSYS Fluent software which could provide accurate results with ease of use and modification before building a prototype product.

It is crucial to understand the structure of a PV panel to acquire accurate results and realize correct simulations. PV panels could have different configuration of layers, depending on the manufacturer and the technology for fabrication. A typical example of the structure was provided by Bayu et al., [17]. The main layers of a PV panel are: exterior glass, ethylene-vinyl acetate (EVA), PV cells, another layer of EVA, and polyvinyl fluoride (PVF) film. Table 1 provides the thermo-physical properties of the layers of a PV panel.

Table 1

Properties of the layers of a photovoltaic panel [17]

\begin{tabular}{lllll}
\hline Layer & Thickness $(\mathrm{m})$ & Thermal Conductivity $(\mathrm{W} / \mathrm{m} \cdot \mathrm{K})$ & Density $\left(\mathrm{kg} / \mathrm{m}^{3}\right)$ & Specific heat capacity $(\mathrm{J} / \mathrm{kg} \cdot \mathrm{K})$ \\
\hline Glass & 0.0032 & 0.7 & 2450 & 790 \\
EVA & 0.0005 & 0.311 & 960 & 2090 \\
PV Cell & 0.0002 & 130 & 2330 & 677 \\
PVF & 0.0003 & 0.15 & 1200 & 1250 \\
\hline
\end{tabular}

\section{Research Methodology}

This paper examines the influence of heat sink on the operating temperature of a PV panel during a clear day in the summer. A unique layer with the thermal characteristics of PV cells was considered as the PV panel. The panel was oriented vertically, with the heat sink attached to the rear surface of the panel. An air channel with a width of $0.1 \mathrm{~m}$ was situated on the back of the module to extract heat from the heat sink by means of convection heat transfer.

Aluminium was selected as the heat sink material due to its high thermal conductivity [18]. Furthermore, its lightweight, ease of machinability, and low cost would be advantageous if a prototype would be realized in further studies. The heat sink was composed of a number of fins attached to a baseplate. The fins were perforated to improve air circulation around the heat sink and to absorb more heat from the panel [19].

Figure 1 shows the proposed geometric design. The heat sink model was created using SolidWorks 2018 and then converted into IGES (.igs) file format before being imported into ANSYS DesignModeller. Circular holes on the fins were placed at a distance of $0.03 \mathrm{~m}$ one to another. Table 2 describes the dimensional characteristics of the heat sink. Fluid domain was created using ANSYS Design Modeller after the heat sink geometry was added. The hydraulic diameter of the air channel was $0.166 \mathrm{~m}$. 


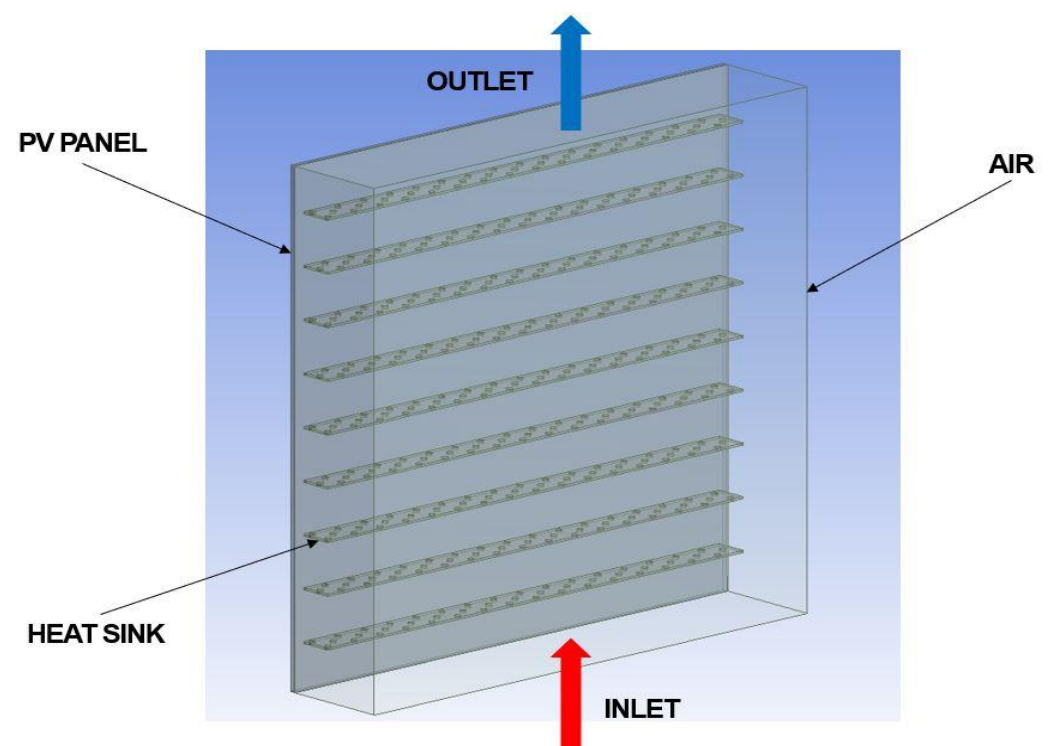

Fig. 1. Heat sink design

Table 2

Dimensional characteristics of the heat sink

\begin{tabular}{ll}
\hline Specifications & Size $(\mathrm{m})$ \\
\hline Fin height & 0.03 \\
Fin length & 0.48 \\
Fin thickness & 0.002 \\
Fin holes diameter & 0.003 \\
Distance between fins & 0.05 \\
Heat sink base length & 0.5 \\
Heat sink base width & 0.5 \\
Heat sink base thickness & 0.002 \\
\hline
\end{tabular}

Meshing was done with cell size of $1 \mathrm{~mm}$ and $2 \mathrm{~mm}$ for the heat sink and $4 \mathrm{~mm}, 6 \mathrm{~mm}$, and 8 $\mathrm{mm}$ for the fluid domain. Mesh independence study was conducted to obtain simulation results which were independent of the number of cells [20] (Figure 2) Different refinements of the mesh are displayed in Figure 3.

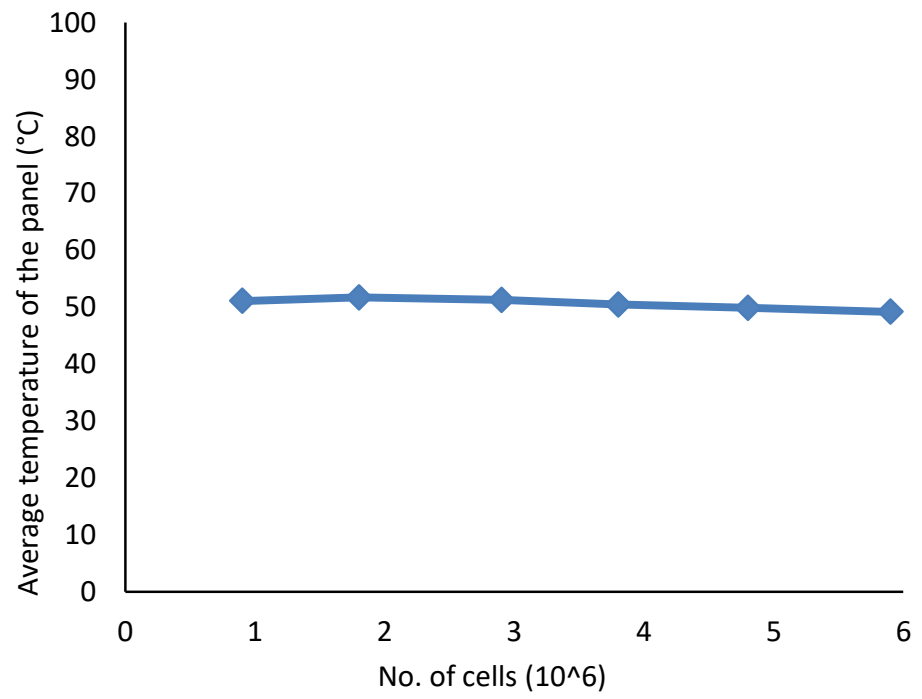

Fig. 2. Mesh independent study 

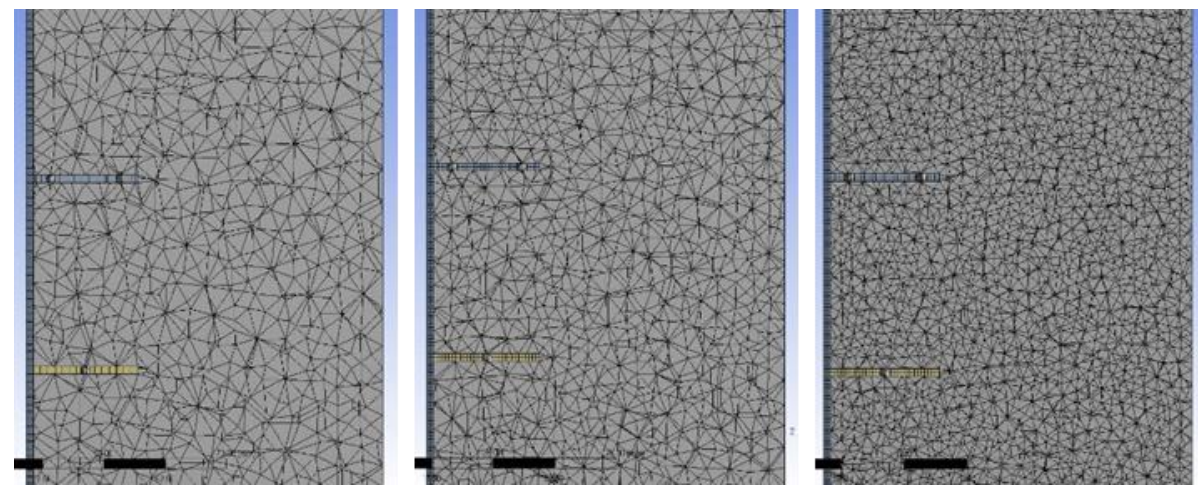

Fig. 3. Different refinements of the mesh, $2 \mathrm{~mm}$ and $8 \mathrm{~mm}$ (left), $1 \mathrm{~mm}$ and $6 \mathrm{~mm}$ (middle), $1 \mathrm{~mm}$ and $4 \mathrm{~mm}$ (right)

Steady-state condition with control volume was assumed for the simulation. Inlet velocity was set at a constant value of $1.5 \mathrm{~m} / \mathrm{s}$. The corresponding Reynolds number for the imposed velocity was 13100 [21], obtained from the equation

$R e=\rho \frac{V L}{\mu}$

For the Reynolds number, turbulent flow regime was considered. Re-Normalization Group (RNG) $\mathrm{k}-\varepsilon$ turbulence model was applied, recommended for air flow inside channels [22]. Turbulence intensity of $4.8 \%$ was estimated using the equation

$I=0.16 \cdot R e^{-\frac{1}{8}}$

Inlet temperature was set to $25^{\circ} \mathrm{C}$, with the normal component of solar radiation applied to the outer surface of the panel using heat flux was varied from $300-1000 \mathrm{~W} / \mathrm{m}^{2}$. Semi-Implicit Method for Pressure-Linked Equation (SIMPLE) scheme was applied for the pressure-velocity coupling, with Second Order Upwind discretization to improve accuracy of the final solution [22]. Convergence criteria of $10^{-6}$ for energy equation and $10^{-3}$ for pressure, velocity and continuity equations was configured for the iterative calculations.

\section{Results and Discussions}

Results of the simulation are presented as contours of temperature distribution across the whole domain and velocity profile of the airflow. Figure 4 represents the base case's temperature spectrum without fins attached. The average temperature reached $38.4^{\circ} \mathrm{C}, 47.2^{\circ} \mathrm{C}$ and $69.4^{\circ} \mathrm{C}$ for heat flux of $300 \mathrm{~W} / \mathrm{m}^{2}, 500 \mathrm{~W} / \mathrm{m}^{2}$, and $1000 \mathrm{~W} / \mathrm{m}^{2}$, respectively.

Temperature range of the case with heat sink installation is shown in Figure 5. Average temperature decreased to $32.3^{\circ} \mathrm{C}, 37.1^{\circ} \mathrm{C}$ and $49.2^{\circ} \mathrm{C}$ for heat flux of $300 \mathrm{~W} / \mathrm{m}^{2}, 500 \mathrm{~W} / \mathrm{m}^{2}$, and 1000 $\mathrm{W} / \mathrm{m}^{2}$, respectively. This shows an improvement of the heat transfer performance from the panel to ambient air. Velocity profiles of the airflow are presented in Figure 6 for cases with fins and without fins under applied heat flux of $500 \mathrm{~W} / \mathrm{m}^{2}$. 

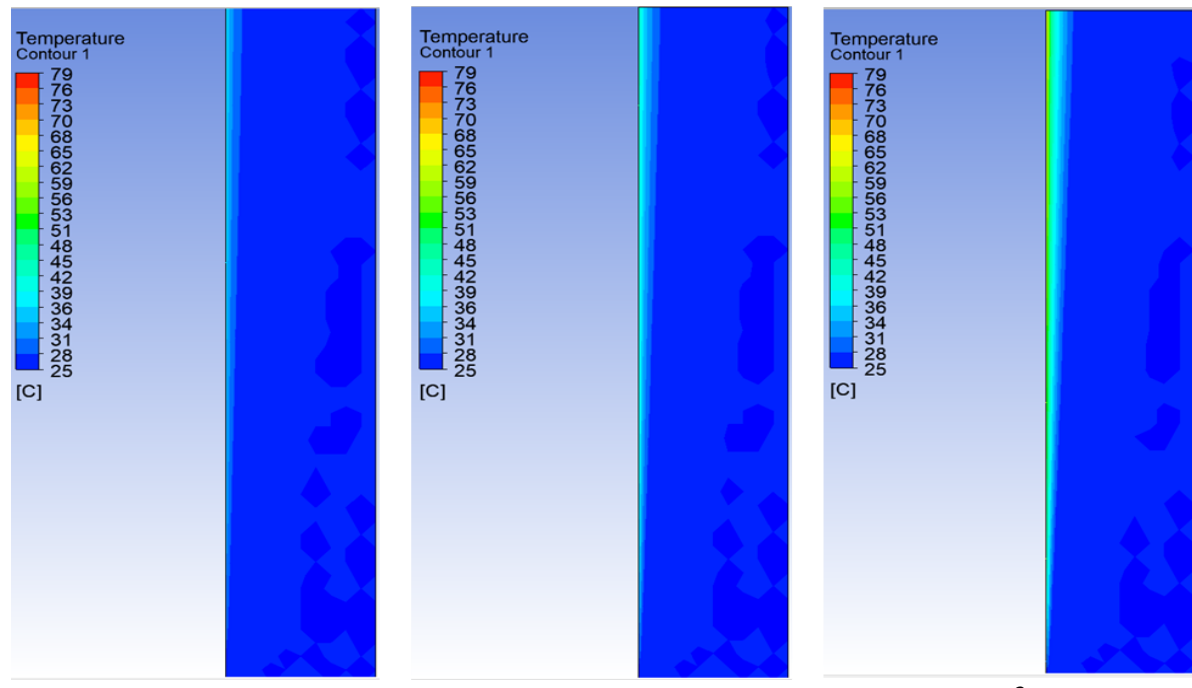

Fig. 4. Base case temperature spectrum for heat flux of $300 \mathrm{~W} / \mathrm{m}^{2}$ (left), 500 $\mathrm{W} / \mathrm{m}^{2}$ (middle), and $1000 \mathrm{~W} / \mathrm{m}^{2}$ (right)
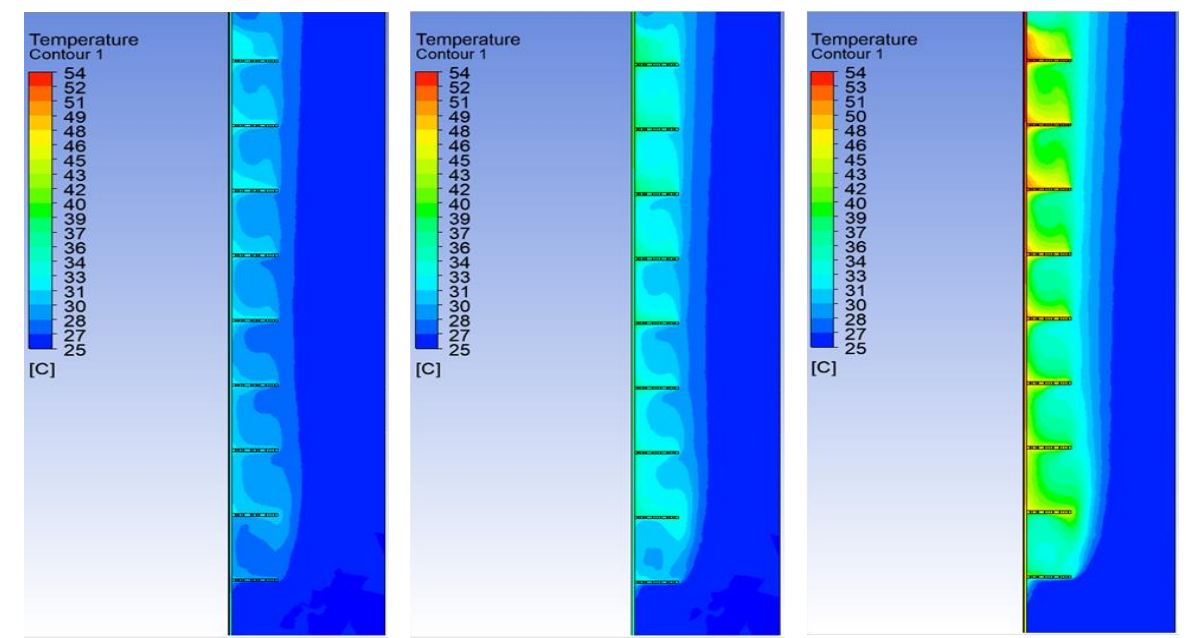

Fig. 5. Temperature spectrum of the case with heat sink for heat flux of 300 $\mathrm{W} / \mathrm{m}^{2}$ (left), $500 \mathrm{~W} / \mathrm{m}^{2}$ (middle), and $1000 \mathrm{~W} / \mathrm{m}^{2}$ (right)
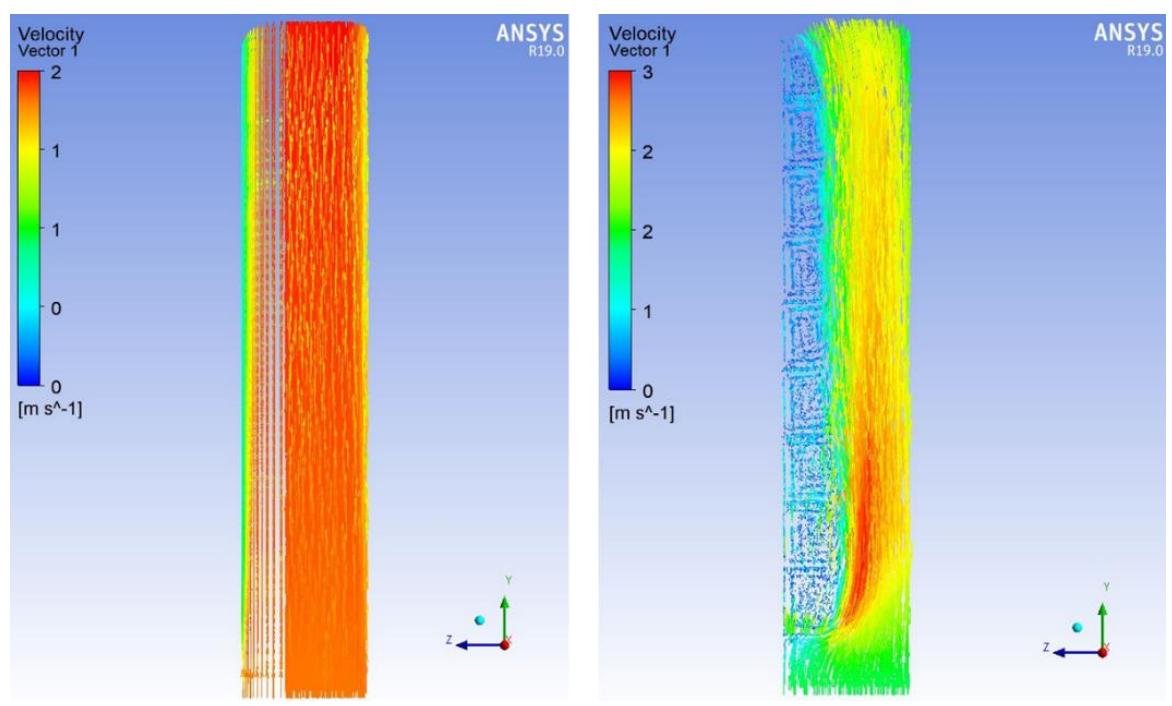

Fig. 6. Velocity profile of the airflow for the base case (left) and case with heat sink (right) 
Figure 7 shows the average temperature of the panel under variable heat flux with heat sink and without heat sink. The increasing amount of heat flux contributes to the rise of the panel's average temperature. Overall average temperature for the case with heat sink is lower than the case without heat sink due to the heat sink provided better rate of heat transfer. The influence of heat sink in reducing the PV panel operating temperature is presented in Table 3. The temperature coefficient is $-0.004 \% /{ }^{\circ} \mathrm{C}$, according to $[23]$.

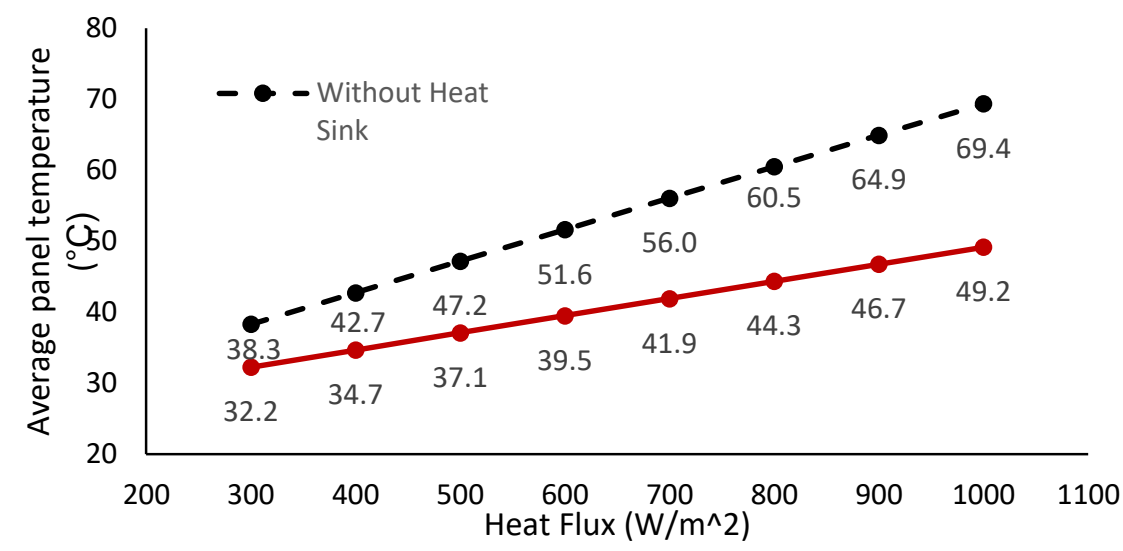

Fig. 7. Average panel temperature under variable heat flux

Table 3

Influence of average operating temperature to PV panel performance

\begin{tabular}{llllllll}
\hline Case & $\begin{array}{l}\text { Heat flux } \\
{\left[\mathrm{W} / \mathrm{m}_{2}\right]}\end{array}$ & $\mathrm{t}_{\text {ave }}\left[{ }^{\circ} \mathrm{C}\right]$ & {$[\%]$ of $\mathrm{P}_{\mathrm{N}}$} & $\eta$ & $\mathrm{Ps}_{\mathrm{s}}\left[\mathrm{W} / \mathrm{m}^{2}\right]$ & $\mathrm{Pel}_{\mathrm{el}}[\mathrm{W}]$ & $\begin{array}{l}\text { Raise over case without } \\
\text { heat sink [\%] }\end{array}$ \\
\hline Without heat sink & 300 & 38.3 & 94.7 & 0.151 & 45.4 & 11.4 & - \\
& 400 & 42.7 & 92.9 & 0.149 & 59.5 & 14.9 & - \\
& 500 & 47.2 & 91.1 & 0.146 & 72.9 & 18.2 & - \\
& 600 & 51.6 & 89.4 & 0.143 & 85.8 & 21.4 & - \\
& 700 & 56 & 87.6 & 0.140 & 98.1 & 24.5 & - \\
With heat sink & 800 & 60.5 & 85.8 & 0.137 & 109.8 & 27.5 & - \\
& 900 & 64.9 & 84 & 0.134 & 121 & 30.3 & - \\
& 1000 & 69.4 & 82.2 & 0.132 & 131.6 & 32.9 & - \\
& 300 & 32.2 & 97.1 & 0.155 & 46.6 & 11.7 & 2.58 \\
& 400 & 34.7 & 96.1 & 0.154 & 61.5 & 15.4 & 3.44 \\
& 500 & 37.1 & 95.2 & 0.152 & 76.1 & 19.0 & 4.43 \\
& 600 & 39.5 & 94.2 & 0.151 & 90.4 & 22.6 & 5.42 \\
& 700 & 41.9 & 93.2 & 0.149 & 104.4 & 26.1 & 6.44 \\
& 800 & 44.3 & 92.3 & 0.148 & 118.1 & 29.5 & 7.55 \\
& 900 & 46.7 & 91.3 & 0.146 & 131.5 & 32.9 & 8.66 \\
& 1000 & 49.2 & 90.3 & 0.145 & 144.5 & 36.1 & 9.82 \\
\hline
\end{tabular}

where $t_{\text {ave }}$ - average temperature of PV panel $\left[{ }^{\circ} \mathrm{C}\right], \mathrm{P}_{\mathrm{N}}-$ nominal power produced at $25^{\circ} \mathrm{C}[\mathrm{W}], \mathrm{\eta}-$ conversion coefficience, $\mathrm{P}_{\mathrm{S}}-$ specific electric power $\left[\mathrm{W} / \mathrm{m}^{2}\right]$, and $\mathrm{P}_{\mathrm{el}}$ - electrical power produced by the studied PV panel [W] 


\section{Conclusions}

The performance of aluminium heat sink as a cooling system for PV panel was studied. Heat sink installation increased the heat transfer area on the back of the PV panel so that the rate of heat transfer from the panel to the ambient air increased. Perforations of the heat sink's fins also aided the air circulation around the fins and created air vortices which increased the heat transfer as well.

For the case without heat sink, maximum produced power could reduce into $82.2 \%$ of the nominal (STP) one when the panel receives heat flux of $1000 \mathrm{~W} / \mathrm{m}^{2}$. For the case with heat sink, maximum produced power could be maintained at $90.3 \%$ of the nominal (STP) one when the panel receives heat flux of $1000 \mathrm{~W} / \mathrm{m}^{2}$, which showed better electrical power output and efficiency, compared to the case without heat sink.

The usage of heat sink could reduce the average operating temperature, ranging from $6-20^{\circ} \mathrm{C}$. The proposed method could represent a cheap and flexible solution for cooling of PV panels. The simulations conducted could also provide valuable insight if an actual prototype or experiment would be realized in the future.

\section{Acknowledgements}

This work partially supported by the grant of PDUPT from the Ministry of Research, Technology, and Higher Education, the Republic of Indonesia with contract number 719/UN.27.21/PN/2019 for FY 2019.

\section{References}

[1] Jäger, Klaus-Dieter, Olindo Isabella, Arno HM Smets, René ACMM van Swaaij, and Miro Zeman. Solar energy: fundamentals, technology and systems. UIT Cambridge, 2016.

[2] United Nations Development Programme. World Energy Assessment. (2000).

[3] International Energy Agency, and Fatih Birol. World energy outlook 2013. Paris: International Energy Agency, 2013.

[4] Hu, Chenming, and Richard M. White. "Solar cells: from basic to advanced systems." (1983).

[5] Wasfi, Mahmud. "Solar energy and photovoltaic systems." Journal of Selected Areas in Renewable and Sustainable Energy, (2011): 1-8.

[6] Dubey, Swapnil, Jatin Narotam Sarvaiya, and Bharath Seshadri. "Temperature dependent photovoltaic (PV) efficiency and its effect on PV production in the world-a review." Energy Procedia 33 (2013): 311-321.

https://doi.org/10.1016/i.egypro.2013.05.072

[7] Radziemska, E. "The effect of temperature on the power drop in crystalline silicon solar cells." Renewable energy 28, no. 1 (2003): 1-12. https://doi.org/10.1016/S0960-1481(02)00015-0

[8] Wu, Shenyi, and Chenguang Xiong. "Passive cooling technology for photovoltaic panels for domestic houses." International Journal of Low-Carbon Technologies 9, no. 2 (2014): 118-126.

https://doi.org/10.1093/ijlct/ctu013

[9] Reddy, Sohail R., Mohammad A. Ebadian, and Cheng-Xian Lin. "A review of PV-T systems: Thermal management and efficiency with single phase cooling." International Journal of Heat and Mass Transfer 91 (2015): 861-871. https://doi.org/10.1016/j.ijheatmasstransfer.2015.07.134

[10] Dong, Jun, Xiaoru Zhuang, Xinhai Xu, Zhihuai Miao, and Ben Xu. "Numerical analysis of a multi-channel active cooling system for densely packed concentrating photovoltaic cells." Energy Conversion and Management 161 (2018): 172-181.

https://doi.org/10.1016/i.enconman.2018.01.081

[11] Hasanuzzaman, M., A. B. M. A. Malek, M. M. Islam, A. K. Pandey, and N. A. Rahim. "Global advancement of cooling technologies for PV systems: A review." Solar Energy 137 (2016): 25-45.

https://doi.org/10.1016/i.solener.2016.07.010

[12] Ali, K., M. Humady, and S. SHawi. "Use of heat sink for solar cell cooling." In Advances In Solar Energy Technology, pp. 349-353. Pergamon, 1988. https://doi.org/10.1016/B978-0-08-034315-0.50074-4

[13] Sato, Daisuke, and Noboru Yamada. "Review of photovoltaic module cooling methods and performance evaluation 
of the radiative cooling method." Renewable and Sustainable Energy Reviews 104 (2019): 151-166. https://doi.org/10.1016/i.rser.2018.12.051

[14] Gotmare, J. A., D. S. Borkar, and P. R. Hatwar. "Experimental investigation of pv panel with fin cooling under natural convection." Int. J. Adv. Technol. Eng. Sci 3, no. 02 (2015): 447-454.

[15] Abd-Elhady, M. S., Z. Serag, and H. A. Kandil. "An innovative solution to the overheating problem of PV panels." Energy conversion and management 157 (2018): 452-459. https://doi.org/10.1016/i.enconman.2017.12.017

[16] Popovici, Cătălin George, Sebastian Valeriu Hudişteanu, Theodor Dorin Mateescu, and Nelu-Cristian Cherecheş. "Efficiency improvement of photovoltaic panels by using air cooled heat sinks." Energy Procedia 85, no. 2016 (2016): 425-432. https://doi.org/10.1016/i.egypro.2015.12.223

[17] Bandung Institute of Technology. Simulation and Experiment of Cooling System for Floating Photovoltaic Module with Thermosiphon Method, 23116301. 2018.

[18] El Mays, Ahmad, Rami Ammar, Mohamad Hawa, Mohamad Abou Akroush, Farouk Hachem, Mahmoud Khaled, and Mohamad Ramadan. "Improving photovoltaic panel using finned plate of aluminum." Energy Procedia 119 (2017): 812-817. https://doi.org/10.1016/j.egypro.2017.07.103

[19] Hudisteanu, Sebastian, Theodor-Dorin Mateescu, Nelu-Cristian Chereches, and Catalin-George Popovici. "Numerical study of air cooling photovoltaic panels using heat sinks." Revista Romana de Inginerie Civila 6, no. 1 (2015): 11-21.

[20] Xu, Haolun, Hsiu-Hung Chen, Sheng Wang, Zheng Li, Kuojiang Li, Greg Stecker, Wei Pan, Jong-Jan Lee, and ChungLung Chen. "Coupled natural convection and radiation heat transfer of hybrid solar energy conversion system." International Journal of Heat and Mass Transfer 107 (2017): 468-483. https://doi.org/10.1016/i.ijheatmasstransfer.2016.11.061

[21] Fox, R. W., A. T. McDonald, P. J. Pritchard, and J. C. Leylegian. "Fluid Mechanics 8th Editions." (2011).

[22] Fluent, A. N. S. Y. S. "ANSYS Fluent User's Guide r15." Chapter 6 (2013): 223-247.

[23] PV Modules LC Series. Henstedt-Ulzburg. 